\title{
ISOLATION AND SELECTION OF FUNGI FROM MATTER AND ORGANIC FERTILIZER PRODUCT JEMBARA BALI'S ORIGIN THAT HAVE THE CAPABILITY TO DISSOLVE THE PHOSPHATE AS BIO-FERTILIZER AGENT
}

\author{
Afny Varitha ${ }^{1}$, Arwan Sugiharta ${ }^{2}$, Marniati Salim \\ ${ }^{1}$ Chemistry Department, Andalas University, Padang \\ ${ }^{2}$ The Indonesian Science and Reserch Institution (LIPI), Bogor Indonesia \\ Email: afnyvaritha@yahoo.com
}

\begin{abstract}
The research about "The isolation and selection of fungi from matter and organic fertilizer product Jembara Bali's origin that have the capability to dissolve the phosphate as Bio-fertilizer agent" have been done on February to June 2010, in The Indonesian Science an Research Institution (LIPI) Bogor. This research aimed to isolate the phosphate solvent fungi from the organic fertilizer product, to identify the kinds of fungi as the Bio-Fertilizer agent, to trial the phosphate dissolve in Laboratorial standard, and then to produce the biofertilizer product. The isolation results of the compos experiment (T1.1 and T1.3) and from the factory compos experiment (T2.1 and T2,2) are identified as Aspergillus sp. The sample of compost experiment (T1.2) is identified as Penicillium $s p$. Whereas, from the sample of an irrigated land (T3.1) is identified as Mycelliasterillia sp. The result of the test in laboratorial scale is resulted the best capability in dissolve the phosphate is Aspergillussp by T2.2 code. This is viewed by the halo zone diameter shaped is bigger than the others fungi's kind, it is around 4,2 cm. The enzyme PME-aseacitivities have been tested in each fungi's species such as : T2.2 (Aspergillus sp), T1.2 (Penicilliumsp), and T3.1 (Mycelliasterillia). The Aspergillus spfungi have the enzyme PME-ase activity is biggest, it is around 1,51 unite/gram. In short, the Aspergillus sp is used as the Bio-fertilizer agent.
\end{abstract}

Key words: The phosphate dissolve fungi, Aspergillus sp, Penicilliumsp, Mycelliasterillia, PME-ase

\section{INTRODUCTION}

Some microorganism lives in the soil and does many activites giving advantages for others living creatures or support others lives naturally. The normal soil is structured by mineral particel, the rest of animals and plants, living system, water which are free or hygroscopic, organic or inorganic salts, gas or soil atmosphere $(\mathrm{CO} 2, \mathrm{O} 2$, N2 and others) (Gunalan, 1996).

Some research institutuion and universities also take apart in developing organic agriculture through researches and giving cultivation technology information which can be applied to agriculture organic.Some efforts which have been done is by introducing biotechnology in organic system by using some microorganism which can help nutrient supply and controlling disease (Alexander, 1978).

The using of soil microbes to increase and maintenance soil fertility is very important in this organic systems. The microbes role is to recycle nutrient, the temporary saving and releasing to use by plants (Alexander, 1978).

The discipline knowledges is really needed to the succes of using microbes which is to increase the soil fertility. The soil microbiologist have started by learn and identify ecology microorganism which used as biofertilizer. The next, microorganism which is 
from soil isolation is expanded in laboratorium condition by using artificial media. The success of this efforts gives wanted strains, not all the species is effective. And then, the effective strains is isolated and researched in the field whether result of inoculation can increase growth and production plants. The inoculation microorganism must be suitable with particular condition and competable or being prayed by the original microorganism (Olsen, 1962).

Soil agriculture microbes is grouped to the two : disadvantegous and advantegous. Disadvantegous (virus, mushroom, bactery, the intruder nematode plants which are as pest and disease). Advantegous such as mushrooms and bactery which have ability to do good metabolism function for growth and plant production. The profitable soil microbial can be named as biofertilizer or organic fertilizer (Olsen, 1962).

Phosphor is macro nutrient which is important to plants growth. In the acid soils, phosphor is combined as Al-P, Fe-P, Occluded$\mathrm{P}$, While in grounded bases, phosphor is combined as Ca-P. By combination of $\mathrm{P}$ causes giving fertilizer is not efficient, so it is needed giving in high dosage. The plants just use $\mathrm{P}$ about $10-30 \%$ from fertilizer $\mathrm{P}$ given , so $70-90 \%$ fertilizer $p$ is still in the soil.

Baceause of this unefficient, the researchers do some researches of using microbes solvent phosphate especially the solvent mushrooms which is as biofertilizer agent or organic fertilizer. (Olsen, 1962).

This research aimed to isolate the phosphate solvent fungi from the organic fertilizer product, to identify the kinds of fungi as the Bio-Fertilizer agent, to trial the phosphate dissolve in Laboratorial standard, and then to produce the biofertilizer product.

\section{MATERIAL AND METHODS}

This research was done by experimentand description methods. Experiment method was done in fungi isolation steps from basic material of making compos in Jemberana, Bali, in where this making compos by using basic material starter and urine. Meanwhile description methods was done by fungi morphology analysis. The other sample which was used is pabric compos, field compos and puddy fields. From those materials was done the fungi isolation by using dilution simple technique.

\subsection{Isolation of fungi to dissolve the phosphate}

Isolation of fungi was done by dilution simple technique. The solid sample such as paddy compos (1), pabric compos (2), and paddy fields (3) were weighed as much 1 grams and for liquid sample such as starter (4) and urine (5) was taken as much $1 \mathrm{~mL}$, then were put into reaction tube which is contained the sterile aquadest as much $9 \mathrm{~mL}$. After that it was done dilution for 7 times by dissolving $1 \mathrm{~mL}$ sample or $1 \mathrm{gr}$ sample put into $9 \mathrm{~mL}$ sterile aquadest. The result of dilution $10^{-2}, 10^{-5}, 10^{-7}$ were taken $0,1 \mathrm{~mL}$ by using micropipette for being cultivated to petridish which is contained PDA and $\mathrm{Ca}_{3}\left(\mathrm{PO}_{4}\right)_{2}$ by using spread plate method by aspetic in Laminar Air Flow. Petridish was incubate for 2-5 days in room temperature $\left(25^{\circ} \mathrm{C}\right)$. This research was done in first day until seventh day (Lehninger, 1990).

\subsection{The density calculation of fungi population}

The sample which was incubated was observed its colony in which growed everyday as long 7 days consequently. And then, it was done the calculation of fungi colony population in which was growed by using Total Plate Count (TPC) (Ponmurugan, 2006).

\subsection{The purification of isolate}

The growing and pure fungi colony was moved to PDA and $\mathrm{Ca}_{3}\left(\mathrm{PO}_{4}\right)_{2}$ medium by using ose needle (Ponmurugan, 2006).

\subsection{The identification of soil fungi}

Identification of soil fungi was done by making microscopicpreparate by metilen blue colouring. The preparate which had been made was observed by using photography microscope Olympus CX-31. The fungi which had been its morphology was matched with identification fungi type book reference, according its morphology characteristic such as location and hyfa form, spore, conidia or its mycelia (Ponmurugan, 2006).

2.5. The test phosphate dissolve in laboratorium scale

To test the ability of fungi dissolving phosphate, each of soils sample was growed to 
the Pikovskaya solid media and was incubated to the room temperature $\left(27-28{ }^{\circ} \mathrm{C}\right)$. The Halozone which is made was showed the ability of fungi to dissolve phosphate. Halozone which was made was measured its diameter and was observed for 3 days (Olsen, 1962).

2.6. The fosfomonoesterase enzyme activity

The standard liquid $20 \mu \mathrm{g} p$-nitrofenol $\mathrm{mL}^{-1}$ was taken $0,1,2,3,4$, and $5 \mathrm{~mL}$ to be put into reaction tube, and then they were diluted with aquadest until their volume $5 \mathrm{~mL}$. Each of liquid was added $1 \mathrm{~mL} \mathrm{CaCl}_{2} 0,5 \mathrm{M}$ and $4 \mathrm{~mL}$ $\mathrm{NaOH}$ 0,5 M. After each liquid was homogenized, so their absorbances was measured by spectrophotometer which has 400 $\mathrm{nm}$ wave long. The PME-ase enzyme activity is stated as unite/soil gram its counted by the formula (Tabatabai, 1982) :

PME-ase activity $=\frac{(\mathrm{S}-\mathrm{C}) \cdot \mathrm{A} \cdot 10.100}{\% \mathrm{dm} \cdot \mathrm{a} \cdot \mathrm{b}}$

Description :

$\begin{array}{ll}\mathrm{S} & =\text { sample concentration }(\mu \mathrm{g} \\ p \mathrm{NP}) & \\ \mathrm{C} & =\text { control concentration }(\mu \mathrm{g} \\ p \mathrm{NP}) & \\ \mathrm{A} & =\text { extract volume }(\mathrm{mL}) \\ \mathrm{B} & =\text { soil weigh }(\mathrm{g}) \\ 10 & =\text { dilution factors } \\ 100 . \%^{-1} \mathrm{dm} & =\text { the weight dry soil factor } \\ \mathrm{a} & =\text { molecul weigh } p \mathrm{NP}(\mathrm{g} / \mathrm{mol}) \\ \mathrm{b} & =\text { incubation time }\end{array}$

\subsection{The fungi spore encapsulation process for biofertilizer}

Encapsulatin process was done by cultivations the pure of isolate fungi and which has the better ability to dissolving phosphate in laboratorium scale, after that the isolate fungi was cultivated to PDA liquid medium in Erlenmeyer. And then its was shaked by shaker for 6 days in room temperature by using $120 \mathrm{rpm}$ speed. The spores of fungi which growed on PDA medium was cultivated by the separating the spore of fungi from growth medium by using filter paper whatman no.1, washed 3 times by using sterile aquadest. The spore of fungi which had been washed,were dried in oven for 2 days at $30^{\circ} \mathrm{C}$. After the spore of fungi was dry, it was grilled by using mortal. This process was done in sterile condition. For encapsulation process was used A and B material(gum, adhesive or kanji), each of them was weighed as much 5 gram and they were dissolved in $50 \mathrm{~mL}$ aquadest and homogenized with stirrer. After all of liquids is homogeny each of liquid was stored in refrigerator at $4{ }^{\circ} \mathrm{C}$. A and $\mathrm{B}$ materials was controlled with $\mathrm{pH} 7-7,5$ by adding $\mathrm{NaOH} / \mathrm{HCl}$ $0,1 \mathrm{~N}$, and then aquadeststeril was added as much $500 \mathrm{~mL}$. A and B liquid was taken each of them $100 \mathrm{~mL}$, to be homogenized, by controlling $\mathrm{pH} 7-7,5$ by adding $\mathrm{HCl} / \mathrm{NaOH} 0,1 \mathrm{~N}$. After that, the $\mathrm{A}$ and $\mathrm{B}$ liquid were combined in beaker glass. To the mixture was added fungi culture and then they were homogenized. The beaker glass which is contained A and B liquid and fungi culture was put on the water bath with 40 ${ }^{\circ} \mathrm{C}$, And then they were homogenized with $\mathrm{pH} 4$. After that, there were let on the ice, until the precipitate exist. The precipitate is separated and washed 3 times by using aquadest with $\mathrm{pH} 4$. After that the water content was deleted by using freeze drying (Rao, 1994).

\section{RESULTS AND DISSCUSSION}

\subsection{Isolation of fungi to dissolve the phosphate}

From these dilution samples, we can see the sample with $\mathrm{T}_{2}$ code $\left(\mathrm{T}_{2.1}, \mathrm{~T}_{2.2}, \mathrm{~T}_{2.3}\right)$ there was fungi population which was many more fungi than other samples. This result is the basic of biofertilizer making process which was from isolate fungi on starter sample was not found the growing fungi colony. On making compos process, starter is the function of N,P and $\mathrm{K}$ source which is needed to microorganism growth, if there are many microorganism, so there will be faster the process of making compos (Lehninger, 1990). 


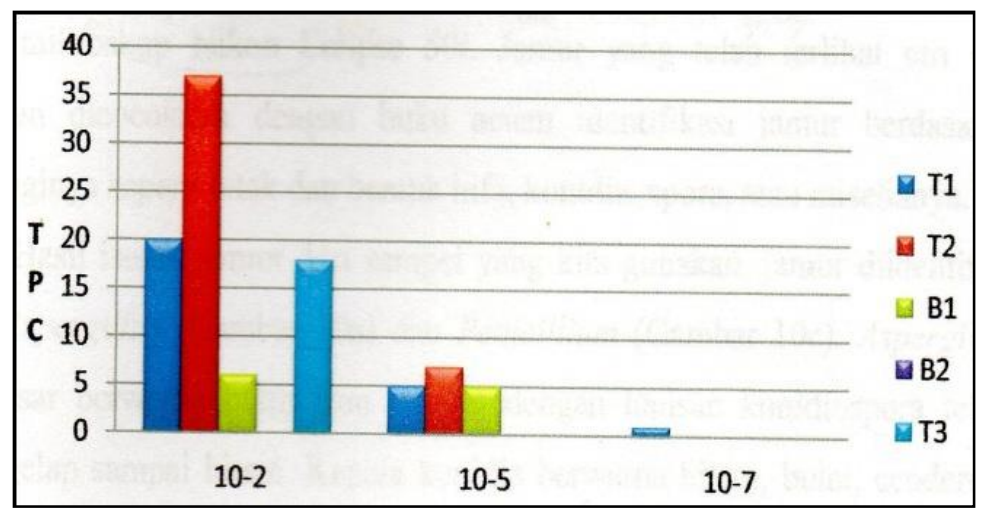

Picture 1 . The density diagram of fungi population

\subsection{The purification of isolate}

By observing macroscopic toward the fungi colony growth on PDA medium, many of growing fungi colony on the sample was cultivated on PDA slants agar by slants agar technique. From $\mathrm{T}_{1.1}, \mathrm{~T}_{2.1}, \mathrm{~T}_{2.2}, \mathrm{~T}_{1.3}, \mathrm{~B}_{1.2}$ and $\mathrm{T}_{3.1}$ were taken each of them 1 fungi colony. Each of fungi colony was moved on PDA media and they were incubated on temperature room. The next fungi isolate were identification by microscope.

\subsection{The identification of fungi}

To know the species of fungi was done the preparation of making preparate and observed by usung Nikon Eclipse 50i microscope. The fungi which had been seen its morphology was matched with identification fungi type boo references, according its morphology characteristic such as location and hyfa form, spore, conidia or its mycelia (Ingold, 1975).

Table 1 . The types of fungi on each sample and dilution

\begin{tabular}{cc}
\hline Isolate code & Fungi types \\
\hline $\mathrm{T}_{1.1}$ & Aspergillus sp, Penicilliumsp \\
$\mathrm{T}_{1.2}$ & Aspergillus sp, Penicilliumsp \\
$\mathrm{T}_{1.3}$ & Aspergillus sp, Penicilliumsp \\
$\mathrm{T}_{2.1}$ & Aspergillus sp, Penicilliumsp \\
$\mathrm{T}_{2.2}$ & Aspergillus sp, Penicilliumsp \\
$\mathrm{T}_{2.3}$ & - \\
$\mathrm{T}_{3.1}$ & Mycelliastrerillia \\
$\mathrm{T}_{3.2}$ & - \\
$\mathrm{T}_{3.3}$ & - \\
$\mathrm{B}_{1.1}$ & - \\
$\mathrm{B}_{1.2}$ & - \\
$\mathrm{B}_{1.3}$ & - \\
$\mathrm{B}_{2.1}$ & - \\
$\mathrm{B}_{2.2}$ & - \\
$\mathrm{B}_{2.3}$ & - \\
\hline
\end{tabular}




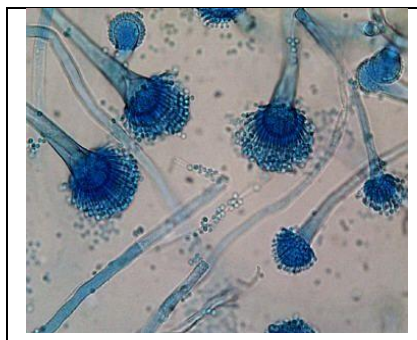

(a)

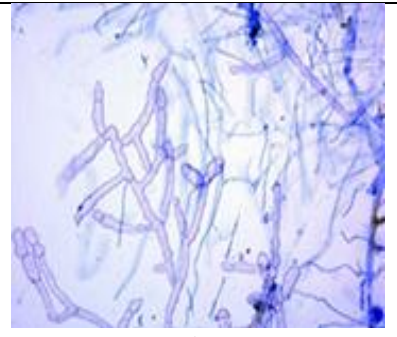

(b)

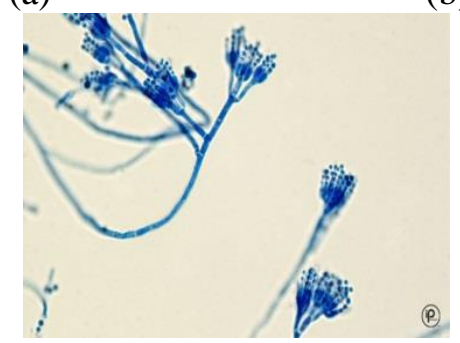

(c)

Figure 2. The fungsi preparate observation by microscopic

(a) Aspergillus sp $\left(\mathrm{T}_{2.2}\right)$

(b) Mycelliasterillia $\left(\mathrm{T}_{3.1}\right)$

(c) Penicilliumsp $\left(\mathrm{T}_{1.2}\right)$

\subsection{The test phosphate dissolve in laboratorium} scale

There some fungi isolate which formed halozone circling the fungi. This showed the ability of fungi on dissolving phosphate. The halozone formation was observed fast, generally was formed one day after ihisisnoculation. This was caused by the dissolving of particle from phosphate calcium. The isolate fungi by $\mathrm{T}_{2.2}$ code which had 4,2 cm diameter. Meanwhile, the smallest halozone clearing area isolate fungi sample $T_{3.1}$ with $1,8 \mathrm{~cm}$ diameter (Ingold, 1975).

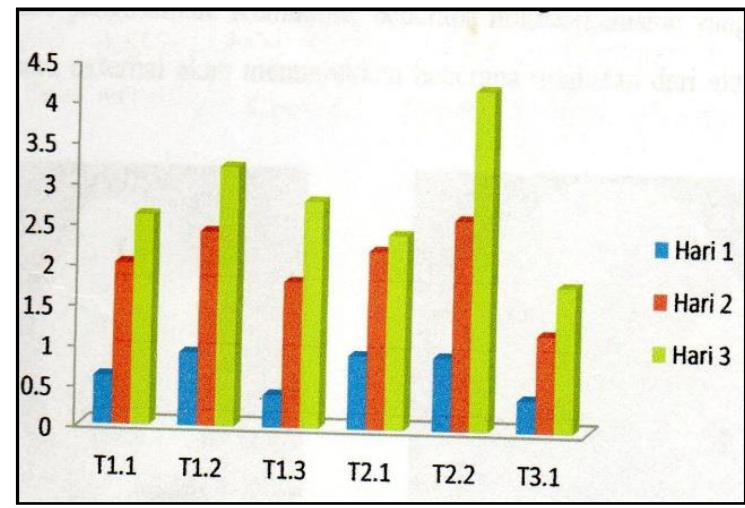

$\mathrm{x}$ axis : sample code y axis : halozone diameter

Figure 3. Observed graphic clearing halozone from each sample from 1-3 days on Pikovskaya medium 
Based on the above graphic, we can see that from day 1 to day 3 halozone kept being bigger. The diameter of halozone which was resulted by Aspergillus sp species from pabric compos and the field compos on the 3 day is the biggest clearing halozone. This showed the ability of dissolving phosphate from Aspergillus species is better than Pencillium species and MycelliaSterillia.The smallest halozone diameter was formed by Mycelliasterillia, this showed the ability to desolved phosphate
Mycelliasterilliaspecies from paddy field is small (Ingold, 1975).

The phosphate microorganism solvent was reported dan dissolve phosphate which was not dissolved through organic acid production or inorganic acid by decreasing $\mathrm{pH}$. Based on the research has been done, the dissolution of $\mathrm{Ca}_{3}\left(\mathrm{PO}_{4}\right)_{2}$ through acid process. And then some microorganism aciditing medium externally showed some stages from phosphate dissolving activity (Ingold, 1975).

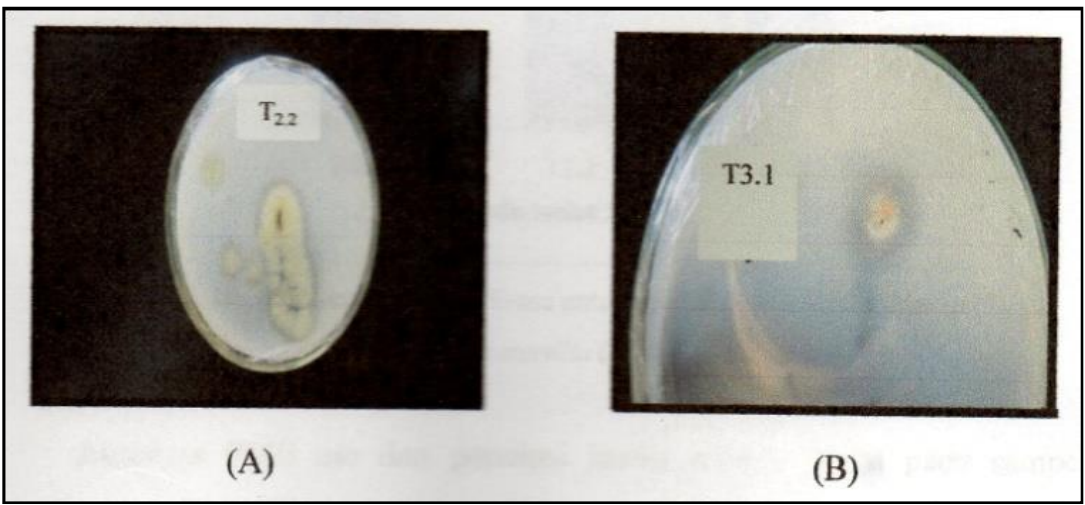

Figure 2. Diameter halozone which are biggest and smallest

(A) The halozone formed by Aspergillus sp $\left(\mathrm{T}_{2.2}\right)$ from field compost

(B) Clearing halozone formed by Mycelliasterillia fungi from paddy field sample

From some fungi isolate making halozone is chosen 3 species which is used to the next procedure ; Aspergillus sp, Penicilliumsp, and Mycelliasterrilia. The fungi isolate was moved to slants PDA medium. Each of them is used to test enzymatic and encapsulation process.

3.5. The fosfomonoesterase activity test

PME-ase enzyme activity from Aspergillus sp made from pabric compos code isolate $\mathrm{T}_{2.2}$ has many high activities is 1,51 unit/gram. For special fungi Penicilliumsp from field compos with isolate $\mathrm{T}_{1.2}$ code has enzymes activity $\quad 0,68$ unit/gram and Mycelliasterilliafrom paddy field with isolate code $\mathrm{T}_{3.1}$ having enzyme activities 0,81 unit/gram. 


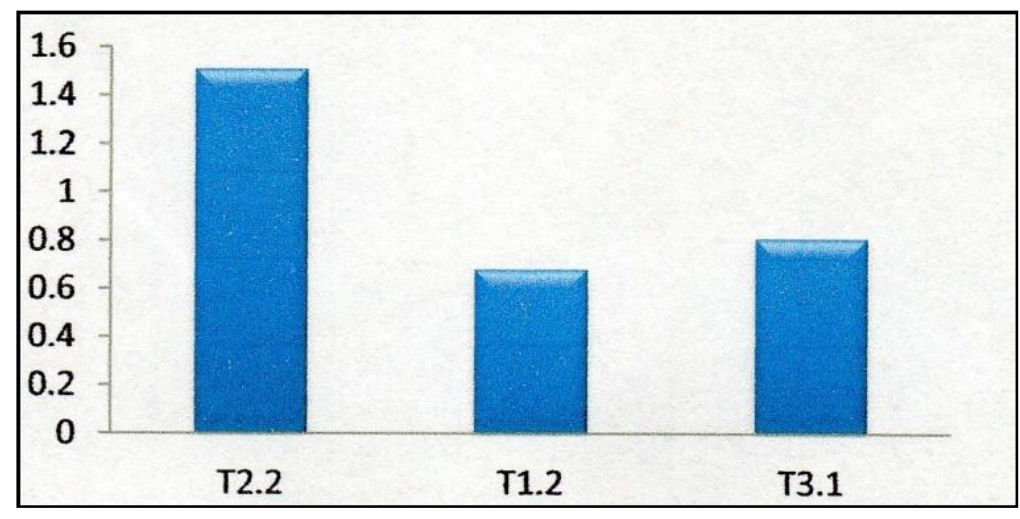

$\mathrm{x}$ axis : isolate fungi code y axis : Enzyme activity

Figure 3. PME-ase enzyme activity for Aspergillus $s p\left(\mathrm{~T}_{2.2}\right)$, Penicilliumsp $\left(\mathrm{T}_{1.2}\right)$ and Mycelliasterillia $\left(\mathrm{T}_{3.3}\right)$

PME-ase activity and fungi dissolvent phosphate population and the compos sample, pabric compos and paddy field indicated that PME-ase enzyme played the important role in fasting mineralization phosphate process and this enzyme was resulted by microorganism phosphate solvent (Tabatabai, 1982).

3.6. The Biofertilizer making process

The isolate fungi to encapsulation process is Aspergillus sp $\left(\mathrm{T}_{2.2}\right)$ because this species is more growing from dilution pabric compos and based on solvent phosphate laboratorium scale. This fungi also made halozone with the highest diameter.

This is the picture where spore which is from phosphate solvent fungi had beenm wrapped by mixture solvent $\mathrm{A}$ and $\mathrm{B}$ or encapsulation process.

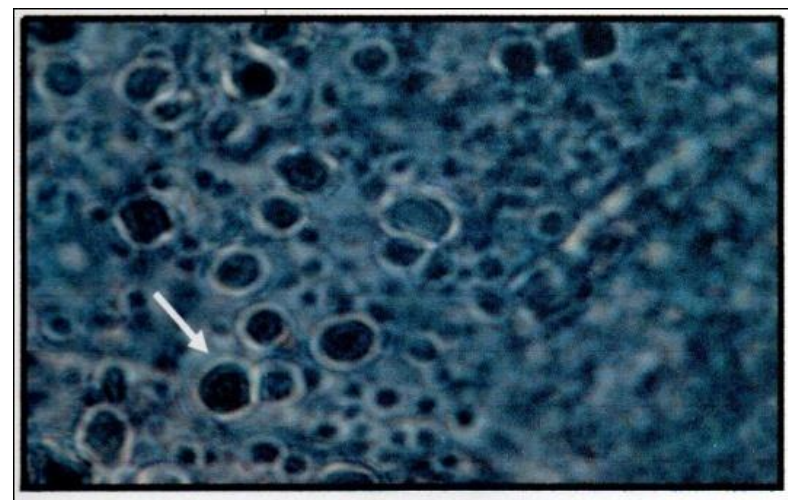

Figure 4. Encapsulation the pore of Aspergillus sp

By observing with Niko Eclipse 50i Microscope with 40x enlargement could be seen that was not all fungi spore wrapped by solvent
$\mathrm{A}$ and $\mathrm{B}$ or not all having encapsulation process. This is caused by homogeny with A and B liquid. For encapsulatin process is done in a short time. 
As longer the homogen process, as many of fungi spore having encapsulation process would be much more (Rachmiati, 1995).

\section{CONCLUSSION}

From this research can be concluded the type of fungi having ability to dissolve phosphate is Aspergillus sp, Penicilliumsp and Mycelliasterillia.By testing the Phospomonoesterase enzyme activities fungi species Aspergillus sp $\left(\mathrm{T}_{2.2}\right)$ had enzyme activity highest.

\section{REFERENCES}

Alexander M. 1978. Introduction to soil Microbiology. $2^{\text {nd }}$ ed. Willey East Limited : New Delhi.

Gunalan. 1996. Penggunan Mikroba Bermanfaat pada Bioteknologi Tanah Berwawasan Lingkungan. Sriwijaya Magazine vol.32.No.2. UniversitasSriwijaya.

Ingold CT. 1975. The Biology of Fungy.Hutchinson Co Publisher.London
Jones, U.S. 1982. Fertilizers and Soil Fertility. $2^{\text {nd }}$ ed. Reston Publ.Co.Reston Virginia.

Lehninger AL. 1990. Dasar-DasarBiokimia 1. MaggyThenawijaya, penerjemah; Terjemahandari : Principle of Biochemistry. Jakarta : Erlangga.

Olsen SR., WD Kemper and RD Jackson. 1962. Phosphate Difusion to Plant Growth. Soil Sci. Soc. Amer. Proc. 26 : 222-227.

Ponmurugan P, Gopi C. 2006. In Vitro Production of Growth Regulator and Phosphatase Activity by Phosphat Solubilizing Bacteria. African Journal of Biotechnology 5 (4) : 348-350.

Rachmiati Y. 1995.Bakteri Pelarut Fosfat dari Rizosfer Tanaman dan Kemampuannya dalam melarutkan Fosfat. ProsedingKongres Nasional VI HITI. Jakarta. 12-15 Desember 1995

Rao NS. Subba. 1994. Mikroorganisme Tanah dan PertumbuhanTanaman. UI Press. Jakarta. P : 274-276.

Tabatabai MA. 1982. Soil Enzymes : Methods of Soil Analysis. Madison:Winconsin 